\title{
Hydrogen cyanide in the upper troposphere: GEM-AQ simulation and comparison with ACE-FTS observations
}

\author{
A. Lupu ${ }^{1}$, J. W. Kaminski ${ }^{1}$, L. Neary ${ }^{1}$, J. C. McConnell ${ }^{1}$, K. Toyota ${ }^{1}$, C. P. Rinsland ${ }^{2}$, P. F. Bernath ${ }^{3,4}$, K. A. Walker ${ }^{5,4}$, \\ C. D. Boone ${ }^{4}$, Y. Nagahama ${ }^{6}$, and K. Suzuki ${ }^{7}$ \\ ${ }^{1}$ Centre for Research in Earth and Space Science, York University, Toronto, Ontario, Canada \\ ${ }^{2}$ NASA Langley Research Center, Hampton, Virginia, USA \\ ${ }^{3}$ Department of Chemistry, University of York, Heslington, UK \\ ${ }^{4}$ Department of Chemistry, University of Waterloo, Waterloo, Ontario, Canada \\ ${ }^{5}$ Department of Physics, University of Toronto, Toronto, Ontario, Canada \\ ${ }^{6}$ Graduate School of Environment and Information Sciences, Yokohama National University, Yokohama, Japan \\ ${ }^{7}$ Faculty of Education and Human Sciences, Yokohama National University, Yokohama, Japan
}

Received: 17 November 2008 - Published in Atmos. Chem. Phys. Discuss.: 23 January 2009

Revised: 24 June 2009 - Accepted: 24 June 2009 - Published: 3 July 2009

\begin{abstract}
We investigate the spatial and temporal distribution of hydrogen cyanide $(\mathrm{HCN})$ in the upper troposphere through numerical simulations and comparison with observations from a space-based instrument. To perform the simulations, we used the Global Environmental Multiscale Air Quality model (GEM-AQ), which is based on the threedimensional global multiscale model developed by the Meteorological Service of Canada for operational weather forecasting. The model was run for the period 2004-2006 on a $1.5^{\circ} \times 1.5^{\circ}$ global grid with 28 hybrid vertical levels from the surface up to $10 \mathrm{hPa}$. Objective analysis data from the Canadian Meteorological Centre were used to update the meteorological fields every $24 \mathrm{~h}$. Fire emission fluxes of gas species were generated by using year-specific inventories of carbon emissions with 8-day temporal resolution from the Global Fire Emission Database (GFED) version 2. The model output is compared with HCN profiles measured by the Atmospheric Chemistry Experiment Fourier Transform Spectrometer (ACE-FTS) instrument onboard the Canadian SCISAT-1 satellite. High values of up to a few ppbv are observed in the tropics in the Southern Hemisphere; the enhancement in $\mathrm{HCN}$ volume mixing ratios in the upper troposphere is most prominent in October. Low upper-tropospheric mixing ratios of less than 100 pptv are mostly recorded at middle and high latitudes in the Southern Hemisphere in May-July. Mixing
\end{abstract}

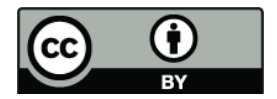

Correspondence to: A. Lupu

(alexlupu@yorku.ca) ratios in Northern Hemisphere peak in the boreal summer. The amplitude of the seasonal variation is less pronounced than in the Southern Hemisphere. The comparison with the satellite data shows that in the upper troposphere GEM-AQ performs well globally for all seasons, except at northern high and middle latitudes in summer, where the model has a large negative bias, and in the tropics in winter and spring, where it exhibits large positive bias. This may reflect inaccurate emissions or possible inaccuracies in the emission profile. The model is able to explain most of the observed variability in the upper troposphere HCN field, including the interannual variations in the observed mixing ratio. A complementary comparison with daily total columns of HCN from two middle latitude ground-based stations in Northern Japan for the same simulation period shows that the model captures the observed seasonal variation and also points to an underestimation of model emissions in the Northern Hemisphere in the summer. The estimated average global emission equals $1.3 \mathrm{Tg} \mathrm{N} \mathrm{yr}^{-1}$. The average atmospheric burden is $0.53 \mathrm{Tg} \mathrm{N}$, and the corresponding lifetime is 4.9 months.

\section{Introduction}

Hydrogen cyanide ( $\mathrm{HCN})$ is a minor constituent of the atmosphere emitted primarily from biomass burning. In the troposphere, it is lost mainly by ocean uptake presumably through biological activity, with a small loss by reaction with $\mathrm{OH}$

Published by Copernicus Publications on behalf of the European Geosciences Union. 
(Singh et al., 2003). Having a relatively simple behaviour and a tropospheric lifetime of several months, $\mathrm{HCN}$ is considered to be a good tracer of biomass burning (e.g., Rinsland et al., 1999, 2000; Li et al., 2003; Yokelson et al., 2003; Rinsland et al., 2007; Nagahama and Suzuki, 2007).

Previous global modelling work focusing on atmospheric HCN was done by Li et al. (2000, 2003). In their study, $\mathrm{Li}$ et al. (2000) showed that seasonal variation of observed HCN total columns at 6 sites in the Northern Hemisphere can be reproduced in a model scenario where biomass burning is the main source and ocean uptake is the main sink. They estimated a global biomass burning HCN source of 1.4-2.9 $\mathrm{Tg} \mathrm{N} \mathrm{yr}^{-1}$ and an atmospheric lifetime for $\mathrm{HCN}$ of 2.1-4.4 months. Li et al. (2003) used a chemistry and transport model, GEOS-CHEM, to analyse HCN observations in the Asian outflow from the Transport and Chemical Evolution over the Pacific (TRACE-P) aircraft mission which was conducted over the Northwest Pacific between February and April 2001 (Singh et al., 2003). Their modelling study confirmed that the ocean is a dominant sink for $\mathrm{HCN}$ and estimated a deposition velocity of $0.13 \mathrm{~cm} \mathrm{~s}^{-1}$ from the observed vertical gradients in the remote marine air. The authors concluded that a global biomass burning source of $0.63 \mathrm{Tg} \mathrm{N} \mathrm{yr}^{-1}$ combined with a residential coal burning source in Asia of $0.20 \mathrm{Tg} \mathrm{N} \mathrm{yr}^{-1}$ provided a best fit to the TRACE-P observations. The resulting atmospheric lifetime of HCN was estimated to be 6.2 months.

Here, we investigate, for the first time, the spatial and temporal distribution of $\mathrm{HCN}$ by comparing global long-term ( $\sim 3$ years) observations in the upper troposphere (UT) from the Atmospheric Chemistry Experiment Fourier transform spectrometer (ACE-FTS) onboard the Canadian SCISAT-1 satellite (Bernath et al., 2005; Boone et al., 2005) with results of numerical simulations performed with the GEM-AQ model (Kaminski et al., 2008).

\section{Model}

The Global Environmental Multiscale Air Quality model (GEM-AQ) is a global, tropospheric chemistry, general circulation model (Kaminski et al., 2008) based on the threedimensional global multi-scale model (GEM) developed by the Meteorological Service of Canada for operational weather forecasting (Côté et al., 1998). The chemical mechanism used in the present study is comprised of 52 gas-phase species and 137 chemical and photolysis reactions. The original mechanism has been expanded to include the oxidation of $\mathrm{HCN}$ by $\mathrm{OH}$. All tracers are advected using the semiLagrangian scheme native to GEM. The vertical transport includes parameterized subgrid scale turbulence and deep convection. Dry deposition is included as a flux boundary condition in the vertical diffusion equation. Wet deposition of gasphase species is treated in a simplified way, and only belowcloud scavenging is considered. The emissions used include yearly-averaged anthropogenic and monthly-averaged biogenic, ocean and soil fluxes, as well as year-specific 8-dayaveraged biomass burning fluxes.

\subsection{Sources of $\mathrm{HCN}$}

Biomass burning emissions were estimated by using yearspecific carbon emissions from the Global Fire Emission Database (GFED) version 2 (van der Werf et al., 2006) resampled to an 8-day temporal resolution using MODIS fire hot spots (Giglio et al., 2003). Emission fluxes were generated by applying emission factors (EF) to the amount of dry matter burned as estimated in GFED version 2. By ecosystem type, the $\mathrm{HCN}$ emission factors (amount of $\mathrm{HCN}$ released per amount of dry matter burned in units of $\mathrm{g} \mathrm{kg}^{-1}$ ) are as follows: 0.43 for savannah and grassland fires (derived from Yokelson et al., 2003), 0.66 for tropical primary deforestation fires (Yokelson et al., 2008), 0.54 for pasture maintenance fires in the Amazon region (Yokelson et al., 2008), and 0.81 for extratropical forest fires (Bertschi et al., 2003a).

We have used the same emission factors regardless of fire characteristics or geographical variations within a particular ecosystem; however, the HCN EF is quite variable. For example, Yokelson et al. (2007) estimated an EF of 1.02 on average for the pine forests surrounding Mexico City. They related their finding to the high nitrogen content in the fuel due to deposition of nitrogen-containing pollutants in the outflow from the Mexico City urban area. Christian et al. (2003) estimated a high average HCN EF of 1.62 for Indonesian fuels, which contain a significant amount of peat. Also, emission factors may depend on the type of combustion. For boreal fires, Bertschi et al. (2003a) reports an HCN EF of 0.69 for smouldering and 0.92 for flaming combustion. In our calculations, we have used the weighted average value of 0.81 from Bertschi et al. (2003a). Interestingly, the HCN EF does not appear to depend on the relative amount of flaming and smouldering combustion for savannah and tropical forest fires (Yokelson et al., 2003, 2008). The EF value of 0.43 used for savannah and grassland was derived from African fire data reported in Yokelson et al. (2003) and Bertschi et al. (2003a). Given that a large part of African savannah fires burn in the wooded savannah (e.g., Justice et al., 1996), we have assigned it a weight of 0.5 when calculating the average HCN EF from the dataset tabulated in Yokelson et al. (2003). HCN EF values in this study ranged from 0.31 for a dambo (flooded grassland) fire in Zambia to 0.76 for a fire in grassland with some brush and small trees in South Africa. The value measured for a miombo (wooded) savannah fire was 0.37. Assuming that residual smouldering combustion of logs represents $10 \%$ of the total fuel consumption, the resulting EF for miombo was estimated to be 0.33 (Bertschi et al., 2003a). It is beyond the scope of this study to address the question of representativeness of these emission factors for each ecosystem. 

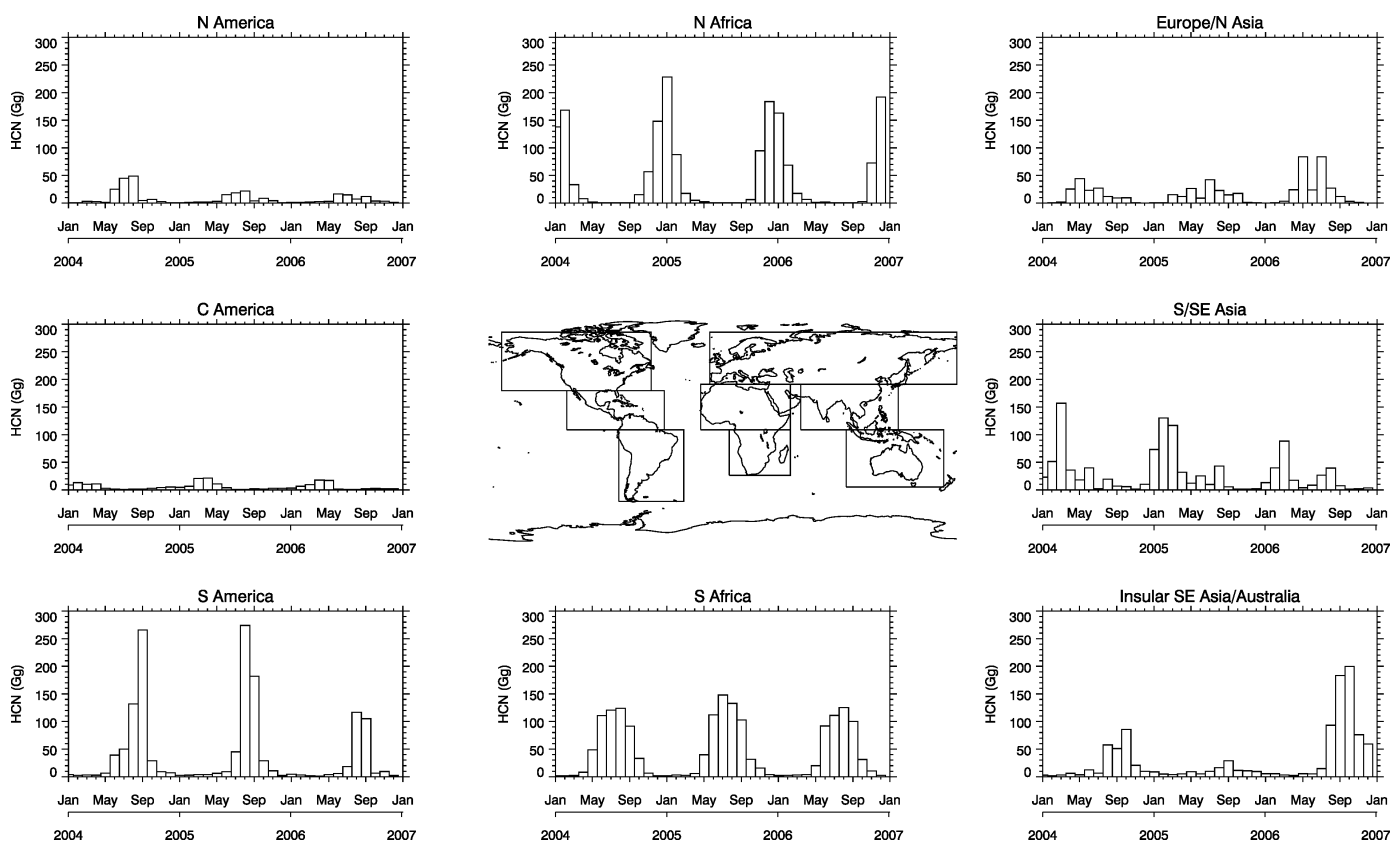

Fig. 1. HCN monthly emissions by geographical region calculated for the period 2004-2006. Regions were defined according to land mass and fire seasonality.

We must note at this point that uncertainties in estimating the emitted amount of biomass burning species are rather large and difficult to quantify. Along with the emission factors, the other two main factors of uncertainty are fuel consumption and burned area (Ito and Penner, 2005). Burned area is considered to be one of the most uncertain factors (Hoelzemann et al., 2004; van der Werf et al., 2006). Comparison between different burned area products for boreal and tropical savannah ecosystems shows that differences are within $20 \%$ for large regions, but interannual differences are larger (not to mention that independent products can exhibit similar biases), while in deforestation regions, burned area estimates are still poorly constrained (van der Werf et al., 2006). Uncertainties in emission estimates are highest in deforestation regions and in regions where peat fires occur (van der Werf et al., 2006). Sinha et al. (2004) estimate that their emissions for African savannah fires are uncertain to $\sim 70 \%$. As a consequence, we will defer refining our $\mathrm{HCN}$ emission inventory until more accurate fire products become available.

Figure 1 shows the HCN monthly emissions calculated for the period 2004-2006 broken down into regional emission areas. The largest fire activity occurs in Africa, contributing about $42 \%$ to the global budget of HCN. The fires in Africa exhibit seasonal variation with peaks in DecemberJanuary in the Northern Hemisphere and in July-August in the Southern Hemisphere. In South and South-east Asia most fire activity takes place from January to April. The smaller peaks during August-September are a result of fires burning
North of the Equator in insular South-East Asia. South of the Equator in South America, burning begins in June and reaches a sharp peak in August-September. The region contributes about $17 \%$ on average to the total budget. In Central America, fires peak in April-May. In North America, Europe and North Asia, most of the fires burn during the boreal summer. The total amount of $\mathrm{HCN}$ emissions averages $1.3 \mathrm{Tg} \mathrm{N} \mathrm{yr}^{-1}$, with less than $4 \%$ variation between the three years used in the analysis. By contrast, Li et al. (2003) and Singh et al. (2003) estimated a total release of $0.83 \mathrm{Tg}$ and $1.1 \mathrm{Tg}$, respectively, for the year 2001. Our global source for that same year amounts to $1.2 \mathrm{Tg}$. Li et al. (2000) estimated a global biomass burning HCN source of $1.4-2.9 \mathrm{Tg} \mathrm{N}^{-1}$.

Another important type of biomass burning is the use of domestic biofuels. A study by Bertschi et al. (2003b) on African biofuels found that biofuel burning is a negligible source of HCN. Small amounts of HCN $\left(\sim 0.01 \mathrm{Tg} \mathrm{N} \mathrm{yr}^{-1}\right)$ are released into the atmosphere from gold mining (Korte and Coulston, 1998). HCN exhaust emissions from vehicles are small (Baum et al., 2007; Karlsson, 2004). Li et al. (2003) argued that enhanced HCN observed in the Chinese urban plumes during TRACE-P could indicate an $\mathrm{HCN}$ source from hard coal burning. They estimated that a total Asian coal burning source of $0.2 \mathrm{Tg} \mathrm{N} \mathrm{yr}^{-1}$ could explain the experimental data. Another possible source of $\mathrm{HCN}$ might be biogenic. It is known that thousands of species of higher plants synthesize cyanogenic glycosides and cyanolipids that, upon tissue disruption, are hydrolysed, releasing HCN (Poulton, 1990). Due to the complex nature of this 
biochemical process, the amount of $\mathrm{HCN}$ released into the atmosphere is difficult to estimate. Based on the TRACE-P data, Singh et al. (2003) estimated a global primary biogenic or secondary source of up to $0.2 \mathrm{Tg} \mathrm{N} \mathrm{yr}^{-1}$ (and just a small anthropogenic source of $<0.05 \mathrm{Tg} \mathrm{N} \mathrm{yr}^{-1}$ ) in order to balance the ocean uptake. On the other hand, Shim et al. (2007) used the positive matrix factorisation (PMF) method (Paatero, 1997) to analyse the same TRACE-P data, and concluded that $41 \%$ of the HCN variability in the measured volume mixing ratios could be explained by a terrestrial biogenic factor. This would mean a much larger biogenic source than previously thought. However, their PMF analysis of data from the Intercontinental Chemical Transport Experiment - North America, phase A (INTEX-A) did not reveal any biogenic factor. Clearly, more experimental work is needed in order to reconcile these contradictory results and to quantify the potential release of $\mathrm{HCN}$ from plants and fossil fuel burning. In our subsequent calculations, all these potential sources were neglected.

In the model, the biomass burning emissions were uniformly injected by mass in a vertical column rather than at the surface, in order to account for the initial rapid lofting induced by the release of heat from the fires (pyroconvection). Injection heights depend on fire intensity and meteorological conditions (Lavoué et al., 2000, 2007), and exhibit a wide range of variation. In most cases, emissions are confined to the boundary layer (Labonne et al., 2007). However, there is evidence that smoke plumes can directly reach the free troposphere (Kahn et al., 2008). Moreover, extreme cases of direct injection into the stratosphere have been observed in boreal regions (e.g., Fromm and Servranckx, 2003; Fromm et al., 2005, 2006; Damoah et al., 2006). Many studies confirm that injection height is an important input parameter to models (de Gouw et al., 2006; O'Neill et al., 2006; Leung et al., 2007; Hyer et al., 2007; Turquety et al., 2007; Freitas et al., 2007; Generoso et al., 2007). For this simulation we assumed prescribed injection heights of $6 \mathrm{~km}$ for North American boreal forests, $3 \mathrm{~km}$ for other boreal forests, $2 \mathrm{~km}$ for temperate forests, and $1 \mathrm{~km}$ for tropical forests, savannah and grassland. The same injection heights, but with a different vertical distribution of emissions have been used in the AeroCom experiments (Dentener et al., 2006). The difference in injection height between North Asia (Russia) and North America is based on the assumption that boreal fires in North America are predominantly intense crown fires, while Russian fires are mostly moderate surface fires (Lavoué et al., 2000). Kasischke et al. (2005), on the other hand, suggests that satellite imagery seems to show that a high percentage of the Russian fires are actually crown fires.

\subsection{Sinks of $\mathrm{HCN}$}

Ocean uptake, presumably through biological degradation, is the main sink for HCN (Singh et al., 2003). Observed vertical gradients of $\mathrm{HCN}$ mixing ratios in remote marine air during the TRACE-P mission were used by Li et al. (2003) and Singh et al. (2003) for estimating the dry deposition velocity of $\mathrm{HCN}$ over the sea surface. By applying a simple steady-state box model for the HCN budget balanced between entrainment from the free troposphere (FT) to the marine boundary layer (MBL), dry deposition to the sea surface and photochemical loss via $\mathrm{OH}$ reaction in the marine boundary layer, Li et al. (2003) obtained $0.13 \mathrm{~cm} \mathrm{~s}^{-1}$, whereas Singh et al. (2003) obtained $0.12 \mathrm{~cm} \mathrm{~s}^{-1}$ with an uncertainty of the order of $20 \%$ solely from the choice of entrainment velocity from FT to MBL. Also, it should be noted that it is reasonable to expect the dry deposition velocity of $\mathrm{HCN}$ to vary with biological activities changing by region, season and wind speed.

In our study we used a deposition velocity of $0.16 \mathrm{~cm} \mathrm{~s}^{-1}$ over oceans and assumed it to be spatially and temporally constant. This value was chosen based on sensitivity runs; it is a larger value than that of $\mathrm{Li}$ et al. (2003) and Singh et al. (2003) and it improves the agreement with ACE observations in the upper troposphere. A decrease in the ocean uptake to $0.13 \mathrm{~cm} \mathrm{~s}^{-1}$ leads to an increase in the global average of HCN mixing ratio in the upper troposphere of about $20 \%$. The global burden is a balance between emissions and (largely) surface loss. Thus, changing either one will affect the burden. Local mixing ratios, however, will depend on local sources, vertical and horizontal emission distributions and long range transport.

Soils are likely not an important sink for HCN (Singh et al., 2003, 2007). Wet scavenging is a minor sink, together with destruction by photolysis and by reaction with $\mathrm{O}\left({ }^{1} \mathrm{D}\right)$ (Cicerone and Zellner, 1983; Kleinböhl et al., 2006). These sinks were neglected. Oxidation by $\mathrm{OH}$ is also minor overall, but significant in the stratosphere, and is implemented using the termolecular reaction rate from Kleinböhl et al. (2006). We have also neglected the production of $\mathrm{HCN}$ from the oxidation of $\mathrm{CH}_{3} \mathrm{CN}$ by $\mathrm{OH}$ in the stratosphere hypothesized by Kleinböhl et al. (2006), who concluded that an $\mathrm{HCN}$ yield of $30 \%$ from the reaction of $\mathrm{CH}_{3} \mathrm{CN}$ with $\mathrm{OH}$ is consistent with a set of $\mathrm{HCN}$ profiles from balloon-borne infrared solar occultation measurements.

\section{Measurements}

SCISAT-1 is a small Canadian satellite that was launched on 12 August 2003 into a $74^{\circ}$ inclined orbit at $650 \mathrm{~km}$ altitude (Bernath et al., 2005). The satellite carries three instruments operating in occultation mode with a shared field of view to take advantage of the high precision of the solar occultation technique.

ACE-FTS, the main instrument onboard, is an infrared Fourier transform spectrometer with a spectral resolution of $0.02 \mathrm{~cm}^{-1}$ from 750 to $4400 \mathrm{~cm}^{-1}$. The instrument is selfcalibrating as low Sun solar spectra are divided by exoatmospheric solar spectra from the same occultation. The 
orbit yields tropical to high latitude occultations in both hemispheres (over the course of one year) with a typical vertical resolution of $3-4 \mathrm{~km}$. The orbit was optimized to provide the largest coverage at high latitudes in winter and spring. Species profiles can be retrieved down to about $5 \mathrm{~km}$ in cloud free situations. The retrieval procedure is described in Boone et al. (2005).

The HCN results employed here are research products, featuring improvements over the official ACE-FTS version $2.2 \mathrm{HCN}$ data products. The research product uses more microwindows than the version 2.2 data product and extends to much higher altitude. Retrievals for the ACEFTS research HCN product employ 10 microwindows between 1395 and $1460 \mathrm{~cm}^{-1}$ and 22 microwindows between 3260 and $3355 \mathrm{~cm}^{-1}$. The altitude range varies with latitude, extending from 8 to $42 \mathrm{~km}$ at the Equator and 6 to $35 \mathrm{~km}$ at the poles, with a $\sin ^{2}$ (latitude) variation to the altitude limits in between. Interferers in the microwindows (retrieved simultaneously with $\mathrm{HCN}$ ) were $\mathrm{H}_{2} \mathrm{O}$ isotopologues $\mathrm{H}_{2}^{16} \mathrm{O}, \mathrm{H}_{2}^{18} \mathrm{O}, \mathrm{H}_{2}{ }^{17} \mathrm{O}$ and $\mathrm{HD}^{16} \mathrm{O}, \mathrm{CO}_{2}$ isotopologues ${ }^{16} \mathrm{O}^{12} \mathrm{C}^{16} \mathrm{O}$ and ${ }^{16} \mathrm{O}^{12} \mathrm{C}^{18} \mathrm{O}, \mathrm{N}_{2} \mathrm{O}$ isotopologues ${ }^{14} \mathrm{~N}^{14} \mathrm{~N}^{16} \mathrm{O}$ and ${ }^{15} \mathrm{~N}^{14} \mathrm{~N}^{16} \mathrm{O}, \mathrm{CH}_{4}$ and $\mathrm{C}_{2} \mathrm{H}_{2}$, with different volume mixing ratio profiles retrieved for different isotopologues of a given molecule.

We note that early in the mission, outgassed water in the ACE-FTS instrument resulted in ice collecting on the cold detector windows. This water has been gradually removed over the course of the mission through periodic heating of the detector assembly. Ice has a broad absorption feature with a peak near $3250 \mathrm{~cm}^{-1}$, and so $\mathrm{HCN}$ microwindows near $3300 \mathrm{~cm}^{-1}$ suffered from poor signal-to-noise for occultations with significant ice contamination on the detectors. Results below $\sim 10 \mathrm{~km}$ come only from the microwindows near $3300 \mathrm{~cm}^{-1}$ (atmospheric $\mathrm{H}_{2} \mathrm{O}$ saturates the region near $1400 \mathrm{~cm}^{-1}$ for altitudes below $\sim 10 \mathrm{~km}$ ). The errors below $10 \mathrm{~km}$ therefore varied strongly early in the mission, depending on the extent of ice buildup on the detectors, but this variability declined in later years as the ice contamination was removed. There was less variability in the errors for results above $10 \mathrm{~km}$ since the region near $1400 \mathrm{~cm}^{-1}$ is not sensitive to ice contamination. Even in the absence of ice, errors above $10 \mathrm{~km}$ are smaller than errors below $10 \mathrm{~km}$ since the signalto-noise ratio near $1400 \mathrm{~cm}^{-1}$, being slightly over $300: 1$, is much larger than it is near $3300 \mathrm{~cm}^{-1}$, i.e., $150: 1$. The statistical fitting error from the least-squares method varies on average from 5\% over high latitudes to $10 \%$ in the tropics at $8.5 \mathrm{~km}$, doubles $1 \mathrm{~km}$ below, and slightly decreases by $1-2 \%$ above $8.5 \mathrm{~km}$ and in the lower stratosphere. The systematic error on the retrieved volume mixing ratios from the spectroscopic constants is 2 to $5 \%$.

HCN data from ACE-FTS have been previously used in other studies. Rinsland et al. (2005) focused on HCN and other biomass burning products in the upper troposphere at lower to middle Southern latitudes for September-November
2004, and Rinsland et al. (2007) analysed ACE-FTS data recorded over Alaska and Canada in June-July 2004, the period with the largest fires on record in Alaska and Yukon Territory, Canada. Coheur et al. (2007) described ACE-FTS observations of various molecules, including $\mathrm{HCN}$, sampling a young biomass burning plume over the East coast of Tanzania in October 2005. Pumphrey et al. (2008) reported the existence of a tropical tape recorder in HCN by analysing tropical stratospheric data from ACE-FTS (covering the period 2004-2007) and from the Microwave Limb Sounder (MLS).

For our present analysis we have used occultations spanning the period from March 2004 to December 2006.

\section{Results}

The model was run for the period $2004-2006$ on a $1.5^{\circ} \times 1.5^{\circ}$ global grid with 28 hybrid vertical levels from the surface up to $10 \mathrm{hPa}$. Objective analysis data from the Canadian Meteorological Centre were used to update the meteorological fields every $24 \mathrm{~h}$. The model was spun up for 4 years in order to achieve quasi-stationarity in the stratosphere, where the photochemical lifetime of $\mathrm{HCN}$ is of the order of several years. The HCN field was saved every hour, and the output was linearly interpolated to the location and time of each sunrise and sunset occultation. The location and time of each occultation were obtained from the latitude, longitude and time of the $30 \mathrm{~km}$ tangent point (calculated geometrically).

Figure 2 displays the observed and modelled time series of $\mathrm{HCN}$ vertical profiles along the satellite track for the entire period. For clarity, the profiles from the sunrise and sunset occultations are shown on separate plots. It can be seen that, in general, the observed features are most of the time well reproduced by the model. The highest values are observed in the tropics in the Southern Hemisphere; the enhancement in $\mathrm{HCN}$ mixing ratios (with values up to a few thousand pptv) in the upper troposphere is most prominent in October (beginning of October for the sunset profiles and end of October for the sunrise profiles). Conversely, both measurements and model show low upper-tropospheric mixing ratios $(<100$ pptv $)$ at middle and high latitudes in the Southern Hemisphere in May-July (sunrise occultations from beginning of May to beginning of June, and sunset occultations from end of June to end of July). On the other hand, high $\mathrm{HCN}$ mixing ratios are observed in the Northern Hemisphere at latitudes $>30^{\circ}$ in May-July (same sunset/sunrise periods as above), but the model underestimates the magnitude of the enhancement. The largest discrepancy can be seen for the month of July 2005 (in the sunset occultation time series).

On Fig. 3 we present a seasonal composite plot of the horizontal distribution of HCN mixing ratios from ACE-FTS and GEM-AQ at an altitude of $8.5 \mathrm{~km}$. A total of 4811 retrievals were available at this altitude for comparison, of which 3198 at latitudes $>60^{\circ}$ and only 399 in the tropics (latitudes $<30^{\circ}$ ). We notice the good overall agreement between model and 

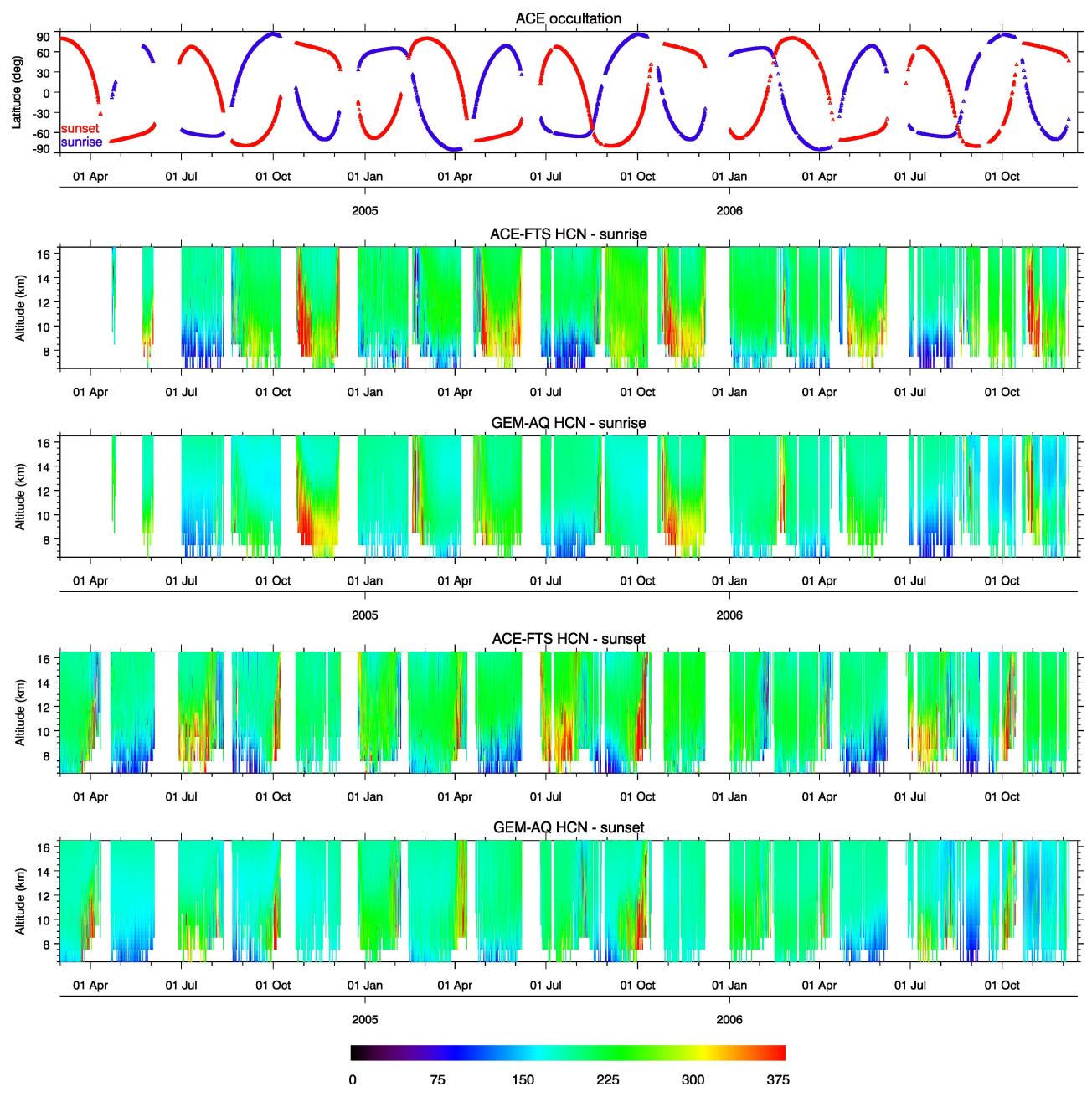

Fig. 2. HCN mixing ratio (pptv) vertical profiles from ACE-FTS and GEM-AQ for sunrise and sunset occultations between March 2004 and December 2006. The model output was interpolated at the location and time of the occultations. End-of-scale red denotes mixing ratios $\geq 375$ pptv.

observations for all seasons, with the notable exception of the Northern Hemisphere at middle and high latitudes in summer and autumn, where the model has negative bias. We complement Fig. 3 with Table 1 in which we provide, for the same altitude, a seasonal statistical summary to illustrate the comparison between model and measurements. The global average of the modelled mixing ratio for all three years of data is about $4 \%$ less than the observed mean. The corresponding standard deviations also compare well, given that variability in model output from a low-resolution run will necessarily be less than that observed. However, we note that the correlation values are rather low. This is most likely a result of large uncertainties in biomass burning emissions and their temporal and spatial distribution, in injection heights and possibly in the loss term, as well as, but to a lower extent, to uncertainties in model transport (with the possible exception of subgrid convective transport).
In order to get a better picture of the seasonal variation of the HCN mixing ratios and of the model performance, we show in Fig. 4 the time series of measured and modelled monthly means at $8.5 \mathrm{~km}$ and $13.5 \mathrm{~km}$ for 30-degree-wide latitude bands. We note the difference between the Southern and Northern Hemispheres at $8.5 \mathrm{~km}$ in the ACE-FTS data: the seasonal variation has a larger amplitude in the Southern Hemisphere. At Northern mid-latitudes the largest peak, which is observed in the summer, has small interannual variation and is less than 350 pptv. By contrast, the observed October peak at Southern mid-latitudes is about $730 \mathrm{pptv}$ in 2005, and its lowest value, in 2006, still reaches about $380 \mathrm{pptv}$. An interesting point is that the model seems to be able to capture this interannual variability of the HCN field in the Southern Hemisphere. September-November 2006, compared with the same period for 2005, was characterised by large fires in Indonesia that may be associated with a 

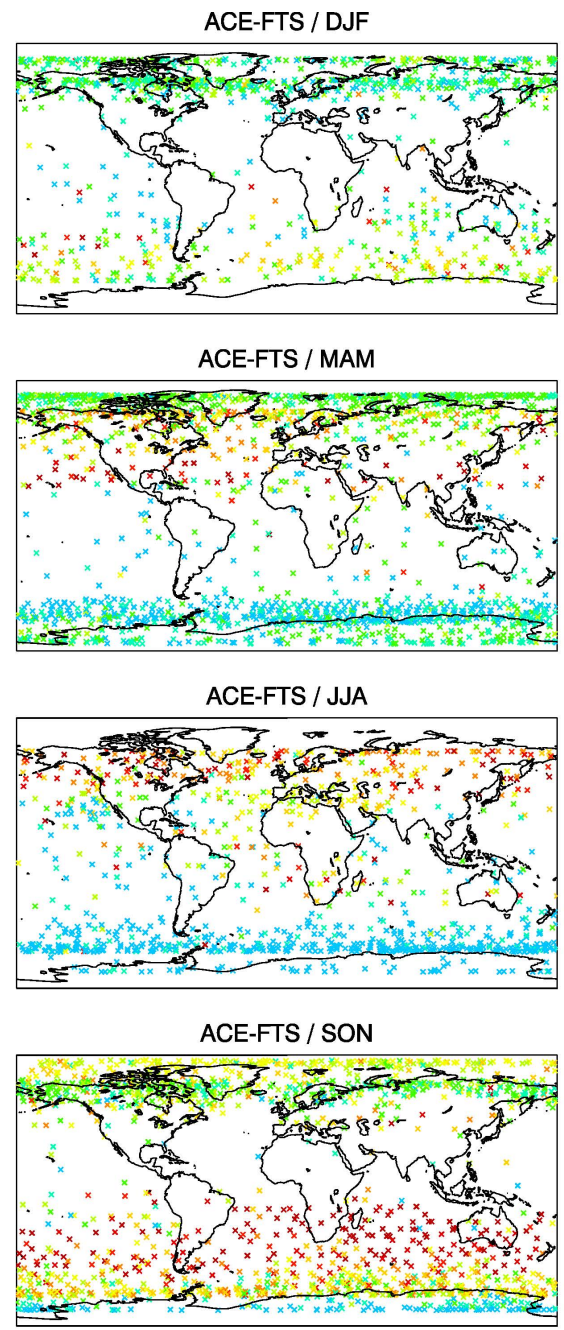
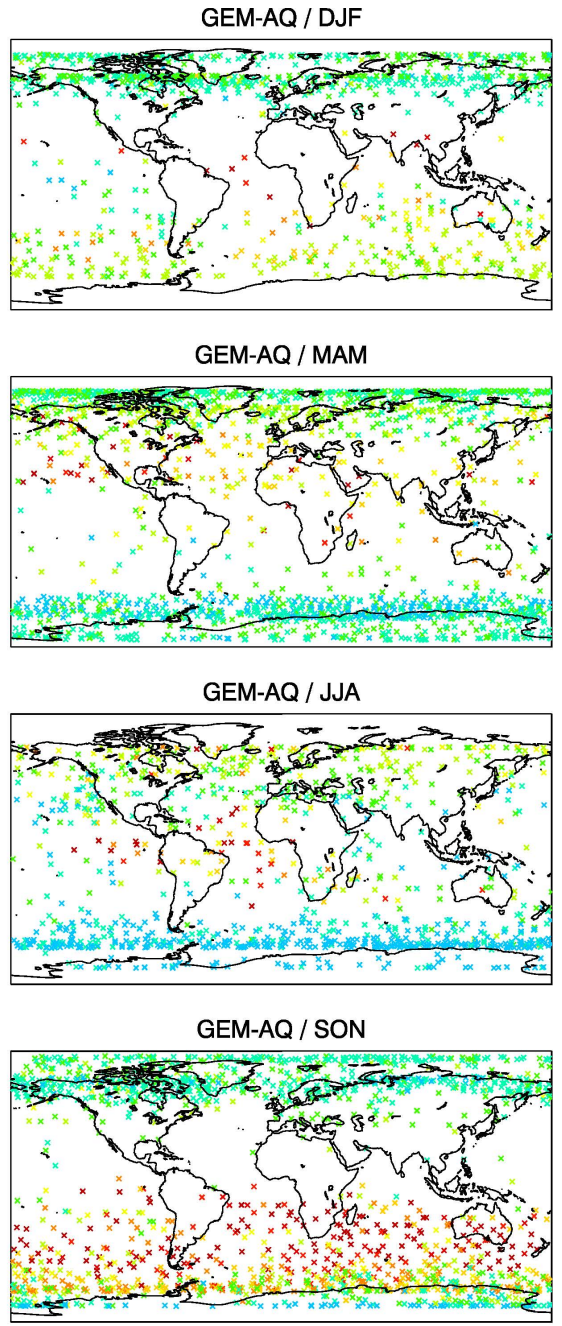

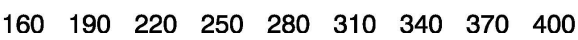

Fig. 3. Composite plot of HCN mixing ratios (pptv) from ACE-FTS and GEM-AQ at $8.5 \mathrm{~km}$ for occultations between March 2004 and December 2006. The model output was interpolated at the location and time of the occultations.

weak El Niño that year (Rinsland et al., 2008; Logan et al., 2008), and low fire activity in South America (Fig. 1). The biomass burning subtropical "megaplume" (Chatfield et al., 2002) generated by the fires in South America and South Africa, and plotted in Fig. 5, was less intense in 2006 than in 2005 , and the difference is reflected, as noted above, in the monthly mixing ratio values for mid-latitudes. Higher mixing ratios from the fires in Indonesia in October 2006 as compared with October 2005 can be seen at higher altitudes in the tropical region (Fig. 4b).

It is interesting to note that the mixing ratio peaks observed in the Southern Hemisphere and depicted in Fig. 4 are offset relative to the emission peaks shown in Fig. 1. For example, in 2005, August was the month with peak HCN emissions, most of which (about $60 \%$ according to our estimation) came out of tropical South America. In September, emissions in South America decreased by about $40 \%$, and in October they became relatively small. Emissions from Africa (the second largest source) also decreased over the same three months. Looking at Fig. 4, we see that, in the Southern Hemisphere, the monthly zonal means at $8.5 \mathrm{~km}$ increased from August to October. In August, tropical South America, the region with the largest emissions, is characterized by subsidence which tends to inhibit deep convection. Thus, the emissions are mostly localized around the source areas and confined to the lower troposphere. This results in relatively small mixing ratios of $\mathrm{HCN}$ in terms of zonal means at altitudes accessible to the ACE instrument. As the dry season breaks down 

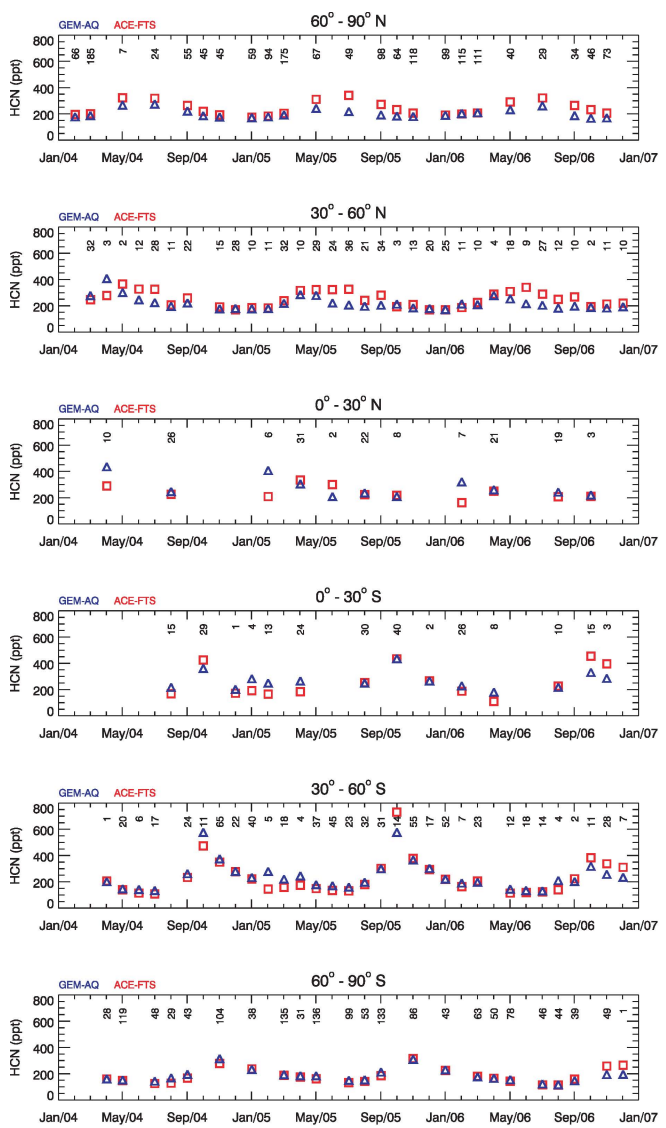

a) $8.5 \mathrm{~km}$ altitude
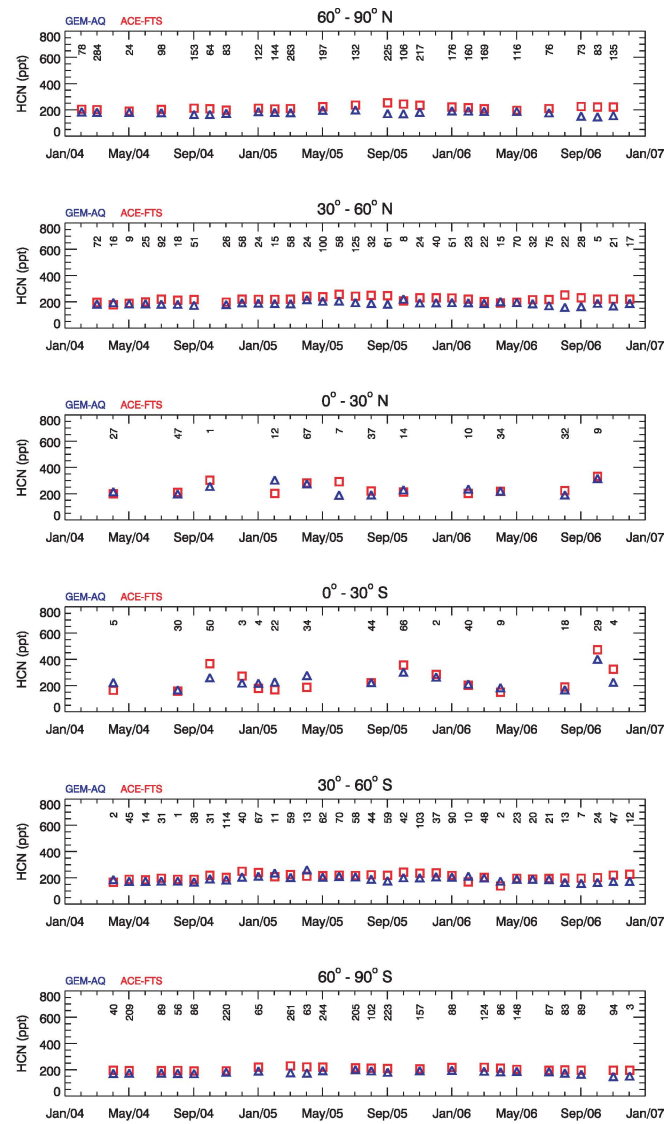

b) $13.5 \mathrm{~km}$ altitude

Fig. 4. Monthly mean time series of HCN mixing ratios (pptv) from ACE-FTS and GEM-AQ at (a) $8.5 \mathrm{~km}$ and (b) $13.5 \mathrm{~km}$ for occultations between March 2004 and December 2006. Number of data used in averaging is displayed beneath the top axis.

in September, synoptic activity starts to loft the emissions, transport them quasi-isentropically to the middle to upper troposphere and towards extratropical latitudes, and spread them zonally. At the same time, the atmospheric burden of $\mathrm{HCN}$ increases over months, due to the long lifetime of the tracer. The net result is the observed increase in the measured mixing ratios.

In the Northern Hemisphere at middle and high latitudes in the summer, GEM-AQ is consistently underpredicting the mixing ratios of $\mathrm{HCN}$. To investigate the issue, we performed two sensitivity runs. In the first run we injected $80 \%$ of boreal forest emissions between 4.5 and $6.5 \mathrm{~km}$ (rather than uniformly between surface and $3 \mathrm{~km}$ for Siberia and surface and $6 \mathrm{~km}$ for North America). The need for such a vertical distribution of emissions, with more mass near the injection height, and with higher injection heights for Siberian fires, is supported by modelling studies such as that of Generoso et al. (2007) focusing on aerosol and CO from the 2003 Russian fires. Turquety et al. (2007) has also shown, for the case of the large Alaskan fires of summer 2004, that bet- ter agreement with observations (MOPITT CO in this case) is obtained when a significant part of emissions is injected in the middle and upper troposphere. We also find that injecting more mass higher improves the agreement between GEM-AQ and ACE-FTS. For example, the underestimation for July 2005 is reduced from $56 \%$ to $25 \%$. In the second sensitivity run we added to the biomass burning source of $1.3 \mathrm{Tg} \mathrm{N} \mathrm{yr}^{-1}$ a global biogenic $\mathrm{HCN}$ source of $0.2 \mathrm{Tg} \mathrm{N} \mathrm{yr}^{-1}$ scaled from the POET (Precursors of ozone and their effects in the troposphere) inventory of biogenic methanol (Olivier et al., 2003), in order to approximate seasonal patterns in vegetation growth. This also reduces the disagreement with measurements at Northern middle and high latitudes in the boreal summer to less than $25 \%$; but the already existing positive bias in the Southern Hemisphere and North of the Equator in the tropics (Table 1) increases. The all-season bias of means reaches $\sim 25 \%$ North of the Equator in the tropics and $\sim 20 \%$ at high Southern latitudes. Due to uncertainties in the estimation of the biomass burning sources, we are unable to either rule out or confirm the existence of a biogenic source 
Table 1. Mean, standard deviation, number of data $(n)$, correlation coefficient $(r)$, and relative mean difference $(d)$ at $8.5 \mathrm{~km}$ by latitude band and season for ACE-FTS and GEM-AQ HCN volume mixing ratios.

\begin{tabular}{|c|c|c|c|c|c|c|}
\hline $\begin{array}{l}\text { Zonal } \\
\text { band }\end{array}$ & Season & $\begin{array}{c}\text { ACE-FTS } \\
\text { (pptv) }\end{array}$ & $\begin{array}{c}\text { GEM-AQ } \\
\text { (pptv) }\end{array}$ & $n$ & $r$ & $\begin{array}{r}d \\
(\%)\end{array}$ \\
\hline \multirow[t]{5}{*}{$60-90^{\circ} \mathrm{N}$} & DJF & $189 \pm 27$ & $186 \pm 16$ & 435 & 0.27 & -1 \\
\hline & MAM & $223 \pm 47$ & $203 \pm 32$ & 585 & 0.68 & -8 \\
\hline & JJA & $330 \pm 54$ & $244 \pm 42$ & 102 & -0.04 & -26 \\
\hline & SON & $231 \pm 39$ & $185 \pm 17$ & 580 & 0.48 & -19 \\
\hline & All & $223 \pm 51$ & $195 \pm 29$ & 1702 & 0.57 & -12 \\
\hline \multirow[t]{5}{*}{$30-60^{\circ} \mathrm{N}$} & DJF & $177 \pm 38$ & $182 \pm 17$ & 115 & 0.26 & 2 \\
\hline & MAM & $275 \pm 71$ & $260 \pm 81$ & 140 & 0.55 & -5 \\
\hline & JJA & $299 \pm 91$ & $211 \pm 32$ & 181 & 0.42 & -29 \\
\hline & SON & $244 \pm 52$ & $199 \pm 21$ & 111 & 0.46 & -18 \\
\hline & All & $256 \pm 83$ & $215 \pm 54$ & 547 & 0.46 & -16 \\
\hline \multirow[t]{5}{*}{$0-30^{\circ} \mathrm{N}$} & DJF & $183 \pm 55$ & $360 \pm 167$ & 13 & 0.52 & 96 \\
\hline & MAM & $289 \pm 127$ & $306 \pm 115$ & 67 & 0.40 & 5 \\
\hline & JJA & $217 \pm 105$ & $242 \pm 86$ & 73 & 0.20 & 11 \\
\hline & SON & $215 \pm 59$ & $212 \pm 49$ & 11 & 0.14 & -1 \\
\hline & All & $244 \pm 115$ & $275 \pm 112$ & 164 & 0.33 & 12 \\
\hline \multirow[t]{5}{*}{$0-30^{\circ} \mathrm{S}$} & DJF & $189 \pm 76$ & $238 \pm 57$ & 47 & 0.45 & 26 \\
\hline & MAM & $164 \pm 65$ & $244 \pm 60$ & 32 & 0.70 & 48 \\
\hline & JJA & $221 \pm 157$ & $235 \pm 74$ & 60 & 0.26 & 6 \\
\hline & SON & $434 \pm 211$ & $383 \pm 159$ & 96 & 0.62 & -11 \\
\hline & All & $294 \pm 200$ & $298 \pm 134$ & 235 & 0.68 & 1 \\
\hline \multirow[t]{5}{*}{$30-60^{\circ} \mathrm{S}$} & DJF & $235 \pm 62$ & $242 \pm 42$ & 151 & 0.48 & 3 \\
\hline & MAM & $157 \pm 50$ & $182 \pm 34$ & 115 & 0.47 & 15 \\
\hline & JJA & $136 \pm 45$ & $162 \pm 40$ & 159 & 0.66 & 19 \\
\hline & SON & $365 \pm 153$ & $356 \pm 140$ & 242 & 0.78 & -2 \\
\hline & All & $245 \pm 140$ & $254 \pm 121$ & 667 & 0.86 & 3 \\
\hline \multirow[t]{5}{*}{$60-90^{\circ} \mathrm{S}$} & DJF & $230 \pm 37$ & $230 \pm 15$ & 82 & 0.42 & 0 \\
\hline & MAM & $164 \pm 33$ & $173 \pm 18$ & 640 & 0.56 & 5 \\
\hline & JJA & $126 \pm 43$ & $142 \pm 22$ & 320 & 0.20 & 12 \\
\hline & SON & $234 \pm 67$ & $245 \pm 70$ & 454 & 0.81 & 4 \\
\hline & $A l l$ & $181 \pm 64$ & $191 \pm 58$ & 1496 & 0.82 & 5 \\
\hline Global & All & $221 \pm 95$ & $212 \pm 77$ & 4811 & 0.72 & -4 \\
\hline
\end{tabular}

of HCN. We also note that the number of data available for comparison in the tropics is rather low.

In order to see how the model performs at higher altitudes, we have plotted in Fig. $4 \mathrm{~b}$ the monthly mean mixing ratios at an altitude of $13.5 \mathrm{~km}$ for the same six latitude bands as in Fig. 4a. The number of valid retrievals used in the plot was 9241 , almost twice as many as that at $8.5 \mathrm{~km}$. It can be noticed that seasonal variations are much less pronounced at this altitude. This is to be expected, since most of the extratropical observations at this altitude are in the lower stratosphere. The model is systematically underestimating the observations by about $10 \%$ on average, ranging from $\sim 3 \%$ in the tropical troposphere to $\sim 15 \%$ over high latitudes. We attribute this difference to our neglecting the $\mathrm{HCN}$ production from $\mathrm{CH}_{3} \mathrm{CN}$ in the stratosphere and possibly to an overestimation of stratospheric $\mathrm{OH}$ that results in faster depletion of $\mathrm{HCN}$. In general, the underestimation in the stratosphere for altitudes up to $20 \mathrm{~km}$ is up to $\sim 12 \%$ globally, with higher values of up to $\sim 20 \%$ at latitudes $>60^{\circ}$.

In addition, we have compared the total $\mathrm{HCN}$ columns measured at Moshiri $\left(44.4^{\circ} \mathrm{N}, 142.3^{\circ} \mathrm{E}, 280 \mathrm{~m}\right.$ a.s.l.) and
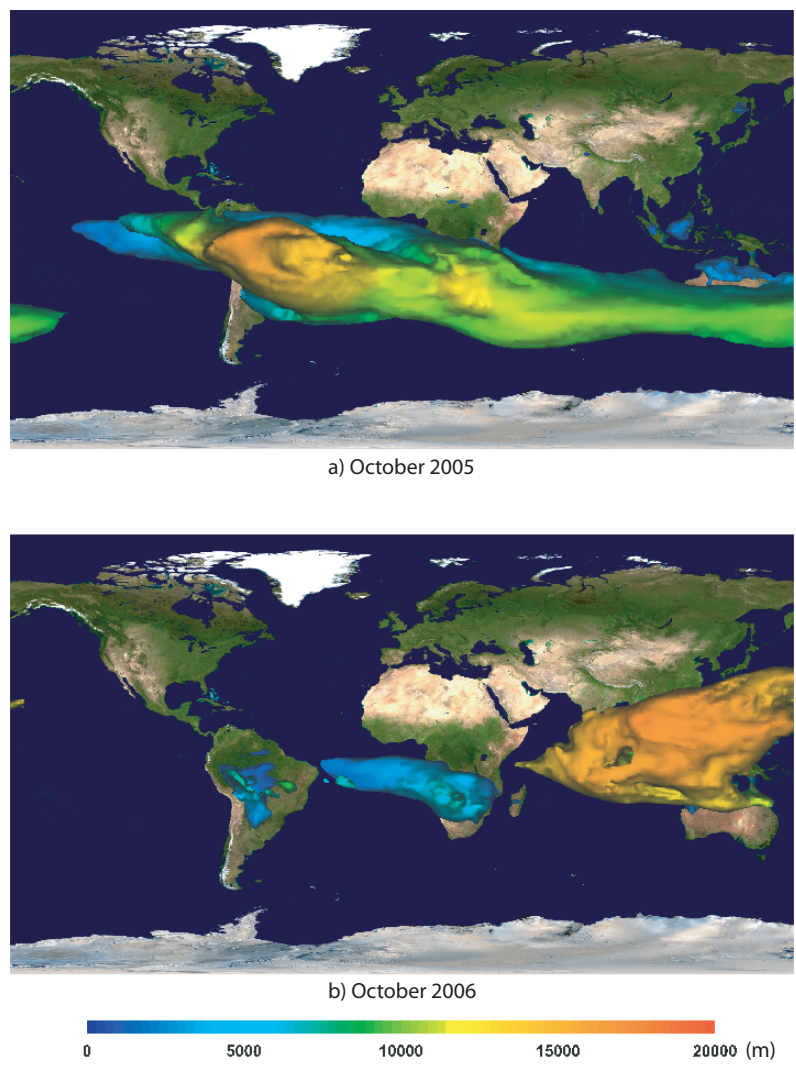

Fig. 5. HCN monthly mean 450-ppt isosurface from GEM-AQ for (a) October 2005 and (b) October 2006. The isosurface is coloured by altitude. The plots were generated with the Integrated Data Viewer (http://www.unidata.ucar.edu/software/idv/).

Rikubetsu $\left(43.5^{\circ} \mathrm{N}, 143.8^{\circ} \mathrm{E}, 370 \mathrm{~m}\right.$ a.s.l.) in Hokkaido, Northern Japan. The total column abundance of HCN has been retrieved from infrared solar spectra for the period overlapping with the ACE observations, i.e., 2004-2006. The spectra were recorded with high spectral resolution groundbased Fourier transform infrared (FTIR) spectrometers. The FTIR spectrometers at Rikubetsu and Moshiri were a Bruker IFS $120 \mathrm{M}$ with resolution of $0.0035 \mathrm{~cm}^{-1}$ and a Bruker IFS $120 \mathrm{HR}$ with resolution of $0.0020 \mathrm{~cm}^{-1}$, respectively. The FTIR spectrometers were installed and operated by the Solar-Terrestrial Environment Laboratory (STEL) of Nagoya University and the spectral data were provided by STEL. The details on the FTIR spectrometers at Moshiri and Rikubetsu are described in Zhao et al. (2002). HCN was retrieved from a single microwindow of $3287.15-3287.37 \mathrm{~cm}^{-1}$. Spectral parameters for the atmospheric $\mathrm{HCN}$ absorption lines were taken from the 2004 edition of the HITRAN database (Rothman et al., 2005). The total column abundance was calculated by SFIT1 version $1.09 \mathrm{e}$. The mean standard deviations of the total column abundance at Rikubetsu and Moshiri are $\sim 3 \%$ and $\sim 1 \%$, respectively. The total uncertainty in the retrieved columns was estimated to be $8 \%$. The column 


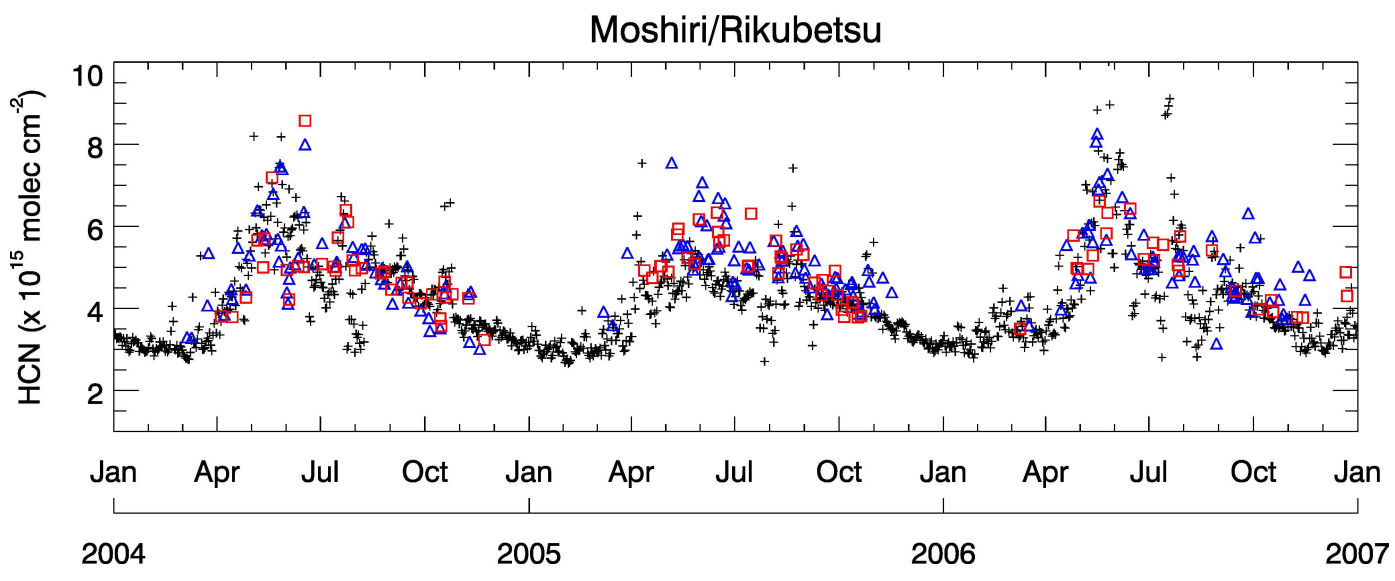

Fig. 6. Daily mean HCN total columns at Moshiri (blue triangles) and Rikubetsu (red squares) in Northern Japan. The measurements were performed with ground-based FTIR spectrometers. Daily-averaged model output is shown as black "plus" signs.

comparison is presented in Fig. 6. Since the distance between the two stations is of the order of the model grid size $\left(1.5^{\circ}\right)$ and the measurements were similar, we have plotted the data from both stations on the same figure, while the model was sampled at the grid point closest to both locations. We must note that averaging kernels were not available and therefore not applied to the model output. Averaging kernels for the HCN total column computed with SFIT2 show that they are broad with vertical sensitivity that peaks in the middle and upper troposphere (Rinsland et al., 1999, Fig. 1). Fig. 6 shows that the model captures the observed seasonal variation, and even individual events like the peaks in mid July and mid October 2004. We also note that the largest discrepancy between model and measurements is for the month of June 2005. During this month the model consistently underestimates the column amount by about $30 \%$. Large mixing ratios at the end of June 2005 over Northern mid-latitudes can also be seen in the ACE-FTS data. Since the columns for the other two years compare reasonably well with the model, we tentatively conclude that emissions in the Northern Hemisphere for 2005 may have been underestimated.

We conclude by presenting the HCN budget from the simulation. We have already stated that the estimated average global emission equals $1.3 \mathrm{Tg} \mathrm{N} \mathrm{yr}^{-1}$. Most of this amount, $1.2 \mathrm{Tg} \mathrm{Nyr}^{-1}$, is taken up by oceans and $0.1 \mathrm{Tg} \mathrm{Nyr}^{-1}$ is oxidised by $\mathrm{OH}$. The average atmospheric burden is about $0.53 \mathrm{Tg} \mathrm{N}$, and the corresponding lifetime is 4.9 months. By comparison, Li et al. (2003) estimated a burden of $0.43 \mathrm{Tg} \mathrm{N}$ and a lifetime of 6.2 months, while Singh et al. (2003) give a value of $0.44 \mathrm{Tg} \mathrm{N}$ for the burden and 5.0 months for the lifetime.

\section{Conclusions}

We have shown that a three-year GEM-AQ simulation performed by using $\mathrm{HCN}$ biomass burning emissions based on GFED version 2 is consistent, in terms of amount and seasonality, with observations of upper-tropospheric $\mathrm{HCN}$ from ACE-FTS. Our model results show that in the upper troposphere GEM-AQ performs well globally for all seasons, except at Northern high and middle latitudes in summer, where the model has large negative bias, and in the tropics in winter and spring, where it exhibits large positive bias. The model is able to explain most of the observed variability in the upper troposphere $\mathrm{HCN}$ field, including the interannual variations in the observed mixing ratio. In our calculations, we assumed a constant value of $0.16 \mathrm{~cm} \mathrm{~s}^{-1}$ for the net ocean uptake. This is a simplifying assumption and may not be accurate. More research is needed in order to constrain the oceanic sink. The injection height is an important modelling parameter for fires in the boreal regions. A better estimation of this parameter is needed. The biomass burning emissions require further refinement. A better characterisation of emissions for different ecosystems is desirable. It is also important to explore and quantify the potential release of $\mathrm{HCN}$ from biogenic sources.

Acknowledgements. The authors wish to acknowledge the financial support from the Canadian Foundation for Climate and Atmospheric Sciences, Environment Canada, the Natural Sciences and Engineering Research Council of Canada, the Canadian Foundation for Innovation, the Ontario Innovation Trust, the Canadian Space Agency and the Natural Environment Research Council of the UK. We thank the Solar-Terrestrial Environment Laboratory of Nagoya University for providing the spectral data from Rikubetsu and Moshiri.

Edited by: A. Richter 


\section{References}

Baum, M., Moss, J., Pastel, S., and Poskrebyshev, G.: Hydrogen Cyanide Exhaust Emissions from In-Use Motor Vehicles, Environ. Sci. Technol., 41, 857-862, doi:10.1021/es061402v, 2007.

Bernath, P. F., McElroy, C. T., Abrams, M. C., Boone, C. D., Butler, M., Camy-Peyret, C., Carleer, M., Clerbaux, C., Coheur, P. F., Colin, R., DeCola, P., DeMazière, M., Drummond, J. R., Dufour, D., Evans, W. F. J., Fast, H., Fussen, D., Gilbert, K., Jennings, D. E., Llewellyn, E. J., Lowe, R. P., Mahieu, E., McConnell, J. C., McHugh, M., McLeod, S. D., Michaud, R., Midwinter, C., Nassar, R., Nichitiu, F., Nowlan, C., Rinsland, C. P., Rochon, Y. J., Rowlands, N., Semeniuk, K., Simon, P., Skelton, R., Sloan, J. J., Soucy, M. A., Strong, K., Tremblay, P., Turnbull, D., Walker, K. A., Walkty, I., Wardle, D. A., Wehrle, V., Zander, R., and Zou, J.: Atmospheric Chemistry Experiment (ACE): Mission overview, Geophys. Res. Lett., 32, L15S01, doi: 10.1029/2005GL022386, 2005.

Bertschi, I., Yokelson, R. J., Ward, D. E., Babbitt, R. E., Susott, R. A., Goode, J. G., and Hao, W. M.: Trace gas and particle emissions from fires in large diameter and belowground biomass fuels, J. Geophys. Res., 108, 8472, doi:10.1029/2002JD002100, 2003a.

Bertschi, I. T., Yokelson, R. J., Ward, D. E., Christian, T. J., and Hao, W. M.: Trace gas emissions from the production and use of domestic biofuels in Zambia measured by open-path Fourier transform infrared spectroscopy, J. Geophys. Res., 108, 8469, doi:10.1029/2002JD002158, 2003b.

Boone, C. D., Nassar, R., Walker, K. A., Rochon, Y., McLeod, S. D., Rinsland, C. P., and Bernath, P. F.: Retrievals for the atmospheric chemistry experiment Fourier-transform spectrometer, Appl. Optics, 44, 7218-7231, doi:10.1364/AO.44.007218, 2005.

Chatfield, R. B., Guo, Z., Sachse, G. W., Blake, D. R., and Blake, N. J.: The subtropical global plume in the Pacific Exploratory Mission-Tropics A (PEM-Tropics A), PEM-Tropics B, and the Global Atmospheric Sampling Program (GASP): How tropical emissions affect the remote Pacific, J. Geophys. Res., 107, 4278, doi:10.1029/2001JD000497, 2002.

Christian, T. J., Kleiss, B., Yokelson, R. J., Holzinger, R., Crutzen, P. J., Hao, W. M., Saharjo, B. H., and Ward, D. E.: Comprehensive laboratory measurements of biomass-burning emissions: 1 . Emissions from Indonesian, African, and other fuels, J. Geophys. Res., 108, 4719, doi:10.1029/2003JD003704, 2003.

Cicerone, R. J. and Zellner, R.: The atmospheric chemistry of hydrogen cyanide (HCN), J. Geophys. Res., 88, 10689-10696, 1983.

Coheur, P.-F., Herbin, H., Clerbaux, C., Hurtmans, D., Wespes, C., Carleer, M., Turquety, S., Rinsland, C. P., Remedios, J., Hauglustaine, D., Boone, C. D., and Bernath, P. F.: ACE-FTS observation of a young biomass burning plume: first reported measurements of $\mathrm{C}_{2} \mathrm{H}_{4}, \mathrm{C}_{3} \mathrm{H}_{6} \mathrm{O}, \mathrm{H}_{2} \mathrm{CO}$ and PAN by infrared occultation from space, Atmos. Chem. Phys., 7, 5437-5446, 2007, http://www.atmos-chem-phys.net/7/5437/2007/. .

Côté, J., Gravel, S., Méthot, A., Patoine, A., Roch, M., and Staniforth, A.: The Operational CMC-MRB Global Environmental Multiscale (GEM) Model. Part I: Design Considerations and Formulation, Mon. Weather Rev., 126, 1373-1395, doi: 10.1175/1520-0493(1998)126〈1373:TOCMGE $\rangle$ 2.0.CO;2, 1998.

Damoah, R., Spichtinger, N., Servranckx, R., Fromm, M., Eloranta, E. W., Razenkov, I. A., James, P., Shulski, M., Forster, C., and
Stohl, A.: A case study of pyro-convection using transport model and remote sensing data, Atmos. Chem. Phys., 6, 173-185, 2006, http://www.atmos-chem-phys.net/6/173/2006/.

de Gouw, J. A., Warneke, C., Stohl, A., Wollny, A. G., Brock, C. A., Cooper, O. R., Holloway, J. S., Trainer, M., Fehsenfeld, F. C., Atlas, E. L., Donnelly, S. G., Stroud, V., and Lueb, A.: Volatile organic compounds composition of merged and aged forest fire plumes from Alaska and western Canada, J. Geophys. Res., 111, D10303, doi:10.1029/2005JD006175, 2006.

Dentener, F., Kinne, S., Bond, T., Boucher, O., Cofala, J., Generoso, S., Ginoux, P., Gong, S., Hoelzemann, J. J., Ito, A., Marelli, L., Penner, J. E., Putaud, J., Textor, C., Schulz, M., van der Werf, G. R., and Wilson, J.: Emissions of primary aerosol and precursor gases in the years 2000 and 1750 prescribed data-sets for AeroCom, Atmos. Chem. Phys., 6, 4321-4344, 2006, http://www.atmos-chem-phys.net/6/4321/2006/.

Freitas, S. R., Longo, K. M., Chatfield, R., Latham, D., Dias, M. A. F. S., Andreae, M. O., Prins, E., Santos, J. C., Gielow, R., and Carvalho Jr., J. A.: Including the sub-grid scale plume rise of vegetation fires in low resolution atmospheric transport models, Atmos. Chem. Phys., 7, 3385-3398, 2007,

http://www.atmos-chem-phys.net/7/3385/2007/.

Fromm, M., Bevilacqua, R., Servranckx, R., Rosen, J., Thayer, J. P., Herman, J., and Larko, D.: Pyro-cumulonimbus injection of smoke to the stratosphere: Observations and impact of a super blowup in northwestern Canada on 3-4 August 1998, J. Geophys. Res., 110, D08205, doi:10.1029/2004JD005350, 2005.

Fromm, M., Tupper, A., Rosenfeld, D., Servranckx, R., and McRae, R.: Violent pyro-convective storm devastates Australia's capital and pollutes the stratosphere, Geophys. Res. Lett., 33, L05815, doi:10.1029/2005GL025161, 2006.

Fromm, M. D. and Servranckx, R.: Transport of forest fire smoke above the tropopause by supercell convection, Geophys. Res. Lett., 30, 1542, doi:10.1029/2002GL016820, 2003.

Generoso, S., Bey, I., Attié, J.-L., and Bréon, F.-M.: A satellite- and model-based assessment of the 2003 Russian fires: Impact on the Arctic region, J. Geophys. Res., 112, D15302, doi:10.1029/ 2006JD008344, 2007.

Giglio, L., Descloitres, J., Justice, C. O., and Kaufman, Y. J.: An Enhanced Contextual Fire Detection Algorithm for MODIS, Remote. Sens. Environ., 87, 273-282, doi:10.1016/S0034-4257(03) 00184-6, 2003.

Hoelzemann, J. J., Schultz, M. G., Brasseur, G. P., Granier, C., and Simon, M.: Global Wildland Fire Emission Model (GWEM): Evaluating the use of global area burnt satellite data, J. Geophys. Res., 109, D14S04, doi:10.1029/2003JD003666, 2004.

Hyer, E. J., Allen, D. J., and Kasischke, E. S.: Examining injection properties of boreal forest fires using surface and satellite measurements of CO transport, J. Geophys. Res., 112, D18307, doi:10.1029/2006JD008232, 2007.

Ito, A. and Penner, J. E.: Estimates of CO emissions from open biomass burning in southern Africa for the year 2000, J. Geophys. Res., 110, D19306, doi:10.1029/2004JD005347, 2005.

Justice, C. O., Kendall, J. D., Dowty, P. R., and Scholes, R. J.: Satellite remote sensing of fires during the SAFARI campaign using NOAA advanced very high resolution radiometer data, J. Geophys. Res., 101, 23851-23863, 1996.

Kahn, R. A., Chen, Y., Nelson, D. L., Leung, F.-Y., Li, Q., Diner, D. J., and Logan, J. A.: Wildfire smoke injection heights: Two 
perspectives from space, Geophys. Res. Lett., 35, L04809, doi: 10.1029/2007GL032165, 2008.

Kaminski, J. W., Neary, L., Struzewska, J., McConnell, J. C., Lupu, A., Jarosz, J., Toyota, K., Gong, S. L., Côté, J., Liu, X., Chance, K., and Richter, A.: GEM-AQ, an on-line global multiscale chemical weather modelling system: model description and evaluation of gas phase chemistry processes, Atmos. Chem. Phys., 8, 3255-3281, 2008,

http://www.atmos-chem-phys.net/8/3255/2008/.

Karlsson, H. L.: Ammonia, nitrous oxide and hydrogen cyanide emissions from five passenger vehicles, Sci. Total Environ., 334335, 125-132, doi:10.1016/j.scitotenv.2004.04.061, 2004.

Kasischke, E. S., Hyer, E. J., Novelli, P. C., Bruhwiler, L. P., French, N. H. F., Sukhinin, A. I., Hewson, J. H., and Stocks, B. J.: Influences of boreal fire emissions on Northern Hemisphere atmospheric carbon and carbon monoxide, Global Biogeochem. Cy., 19, GB1012, doi:10.1029/2004GB002300, 2005.

Kleinböhl, A., Toon, G. C., Sen, B., Blavier, J.-F. L., Weisenstein, D. K., Strekowski, R. S., Nicovich, J. M., Wine, P. H., and Wennberg, P. O.: On the stratospheric chemistry of hydrogen cyanide, Geophys. Res. Lett., 33, L11806, doi:10.1029/ 2006GL026015, 2006.

Korte, F. and Coulston, F.: Some Considerations on the Impact on Ecological Chemical Principles in Practice with Emphasis on Gold Mining and Cyanide, Ecotox. Environ. Safe., 41, 119-129, doi:10.1006/eesa.1998.1692, 1998.

Labonne, M., Bréon, F.-M., and Chevallier, F.: Injection height of biomass burning aerosols as seen from a spaceborne lidar, Geophys. Res. Lett., 34, L11806, doi:10.1029/2007GL029311, 2007.

Lavoué, D., Liousse, C., Cachier, H., Stocks, B. J., and Goldammer, J. G.: Modeling of carbonaceous particles emitted by boreal and temperature wildfires at northern latitudes, J. Geophys. Res., 105, 26871-26890, 2000.

Lavoué, D., Gong, S., and Stocks, B. J.: Modelling emissions from Canadian wildfires: a case study of the 2002 Quebec fires, Int. J. Wildland Fire, 16, 649-663, doi:10.1071/WF06091, 2007.

Leung, F.-Y. T., Logan, J. A., Park, R., Hyer, E., Kasischke, E., Streets, D., and Yurganov, L.: Impacts of enhanced biomass burning in the boreal forests in 1998 on tropospheric chemistry and the sensitivity of model results to the injection height of emissions, J. Geophys. Res., 112, D10313, doi:10.1029/ 2006JD008132, 2007.

Li, Q., Jacob, D. J., Bey, I., Yantosca, R. M., Zhao, Y., Kondo, Y., and Notholt, J.: Atmospheric hydrogen cyanide (HCN): biomass burning source, ocean sink?, Geophys. Res. Lett., 27, 357-360, 2000.

Li, Q. B., Jacob, D. J., Yantosca, R. M., Heald, C. L., Singh, H. B., Koike, M., Zhao, Y. J., Sachse, G. W., and Streets, D. G.: A global three-dimensional model analysis of the atmospheric budgets of $\mathrm{HCN}$ and $\mathrm{CH}_{3} \mathrm{CN}$ : Constraints from aircraft and ground measurements, J. Geophys. Res., 108, 8827, doi: 10.1029/2002JD003075, 2003.

Logan, J. A., Megretskaia, I., Nassar, R., Murray, L. T., Zhang, L., Bowman, K. W., Worden, H. M., and Luo, M.: Effects of the 2006 El Niño on tropospheric composition as revealed by data from the Tropospheric Emission Spectrometer (TES), Geophys. Res. Lett., 35, L03816, doi:10.1029/2007GL031698, 2008.

Nagahama, Y. and Suzuki, K.: The influence of forest fires on CO, $\mathrm{HCN}, \mathrm{C}_{2} \mathrm{H}_{6}$, and $\mathrm{C}_{2} \mathrm{H}_{2}$ over northern Japan measured by in- frared solar spectroscopy, Atmos. Environ., 41, 9570-9579, doi: 10.1016/j.atmosenv.2007.08.043, 2007.

Olivier, J. J., Peters, J., Granier, C., Pétron, G., Müller, J. F., and Wallens, S.: Present and future surface emissions of atmospheric compounds, POET report \#2, EU project EVK2-1999-00011, http://www.aero.jussieu.fr/projet/ACCENT/POET.php, 2003.

O’Neill, N. T., Campanelli, M., Lupu, A., Thulasiraman, S., Reid, J. S., Aubé, M., Neary, L., Kaminski, J. W., and McConnell, J. C.: Evaluation of the GEM-AQ air quality model during the Quebec smoke event of 2002: Analysis of extensive and intensive optical disparities, Atmos. Environ., 40, 3737-3749, doi: 10.1016/j.atmosenv.2006.03.006, 2006.

Paatero, P.: Least squares formulation of robust non-negative factor analysis, Chemometr. Intell. Lab., 37, 23-35, doi:10.1016/ S0169-7439(96)00044-5, 1997.

Poulton, J. E.: Cyanogenesis in plants, Plant Physiol., 94, 401-405, 1990.

Pumphrey, H. C., Boone, C., Walker, K. A., Bernath, P., and Livesey, N. J.: Tropical tape recorder observed in HCN, Geophys. Res. Lett., 35, L05801, doi:10.1029/2007GL032137, 2008.

Rinsland, C. P., Goldman, A., Murcray, F. J., Stephen, T. M., Pougatchev, N. S., Fishman, J., David, S. J., Blatherwick, R. D., Novelli, P. C., Jones, N. B., and Connor, B. J.: Infrared solar spectroscopic measurements of free tropospheric $\mathrm{CO}, \mathrm{C}_{2} \mathrm{H}_{6}$, and HCN above Mauna Loa, Hawaii: Seasonal variations and evidence for enhanced emissions from the Southeast Asian tropical fires of 1997-1998, J. Geophys. Res., 104, 18667-18680, 1999.

Rinsland, C. P., Mahieu, E., Zander, R., Demoulin, P., Forrer, J., and Buchmann, B.: Free tropospheric $\mathrm{CO}, \mathrm{C}_{2} \mathrm{H}_{6}$, and $\mathrm{HCN}$ above central Europe: Recent measurements from the Jungfraujoch station including the detection of elevated columns during 1998, J. Geophys. Res., 105, 24235-24250, 2000.

Rinsland, C. P., Dufour, G., Boone, C. D., Bernath, P. F., and Chiou, L.: Atmospheric Chemistry Experiment (ACE) measurements of elevated Southern Hemisphere upper tropospheric $\mathrm{CO}, \mathrm{C}_{2} \mathrm{H}_{6}$, $\mathrm{HCN}$, and $\mathrm{C}_{2} \mathrm{H}_{2}$ mixing ratios from biomass burning emissions and long-range transport, Geophys. Res. Lett., 32, L20803, doi: 10.1029/2005GL024214, 2005.

Rinsland, C. P., Dufour, G., Boone, C. D., Bernath, P. F., Chiou, L., Coheur, P.-F., Turquety, S., and Clerbaux, C.: Satellite boreal measurements over Alaska and Canada during June-July 2004: Simultaneous measurements of upper tropospheric CO, $\mathrm{C}_{2} \mathrm{H}_{6}, \mathrm{HCN}, \mathrm{CH}_{3} \mathrm{Cl}, \mathrm{CH}_{4}, \mathrm{C}_{2} \mathrm{H}_{2}, \mathrm{CH}_{3} \mathrm{OH}, \mathrm{HCOOH}$, OCS, and $\mathrm{SF}_{6}$ mixing ratios, Global Biogeochem. Cy., 21, GB3008, doi: 10.1029/2006GB002795, 2007.

Rinsland, C. P., Luo, M., Shephard, M. W., Clerbaux, C., Boone, C. D., Bernath, P. F., Chiou, L., and Coheur, P.: Tropospheric emission spectrometer (TES) and atmospheric chemistry experiment (ACE) measurements of tropospheric chemistry in tropical southeast Asia during a moderate El Niño in 2006, J. Quant. Spectrosc. Ra., 109, 1931-1942, doi:10.1016/j.jqsrt.2007.12. 020, 2008.

Rothman, L., Jacquemart, D., Barbe, A., Benner, D. C., Birk, M., Brown, L., Carleer, M., Chackerian Jr., C., Chance, K., Coudert, L., Dana, V., Devi, V., Flaud, J., Gamache, R., Goldman, A., Hartmann, J., Jucks, K., Maki, A., Mandin, J., Massie, S., Orphal, J., Perrin, A., Rinsland, C., Smith, M., Tennyson, J., Tolchenov, R., Toth, R., Auwera, J. V., Varanasi, P., and Wagner, G.: The HITRAN 2004 molecular spectroscopic database, J. 
Quant. Spectrosc. Ra., 96, 139-204, doi:10.1016/j.jqsrt.2004.10. 008, 2005.

Shim, C., Wang, Y., Singh, H. B., Blake, D. R., and Guenther, A. B.: Source characteristics of oxygenated volatile organic compounds and hydrogen cyanide, J. Geophys. Res., 112, D10305, doi:10. 1029/2006JD007543, 2007.

Singh, H. B., Salas, L., Herlth, D., Kolyer, R., Czech, E., Viezee, W., Li, Q., Jacob, D. J., Blake, D., Sachse, G., Harward, C. N., Fuelberg, H., Kiley, C. M., Zhao, Y., and Kondo, Y.: In situ measurements of $\mathrm{HCN}$ and $\mathrm{CH}_{3} \mathrm{CN}$ over the Pacific Ocean: Sources, sinks, and budgets, J. Geophys. Res., 108, 8795, doi: 10.1029/2002JD003006, 2003.

Singh, H. B., Salas, L., Herlth, D., Kolyer, R., Czech, E., Avery, M., Crawford, J. H., Pierce, R. B., Sachse, G. W., Blake, D. R., Cohen, R. C., Bertram, T. H., Perring, A., Wooldridge, P. J., Dibb, J., Huey, G., Hudman, R. C., Turquety, S., Emmons, L. K., Flocke, F., Tang, Y., Carmichael, G. R., and Horowitz, L. W.: Reactive nitrogen distribution and partitioning in the North American troposphere and lowermost stratosphere, J. Geophys. Res., 112, D12S04, doi:10.1029/2006JD007664, 2007.

Sinha, P., Hobbs, P. V., Yokelson, R. J., Blake, D. R., Gao, S., and Kirchstetter, T. W.: Emissions from miombo woodland and dambo grassland savanna fires, J. Geophys. Res., 109, D11305, doi:10.1029/2004JD004521, 2004.

Turquety, S., Logan, J. A., Jacob, D. J., Hudman, R. C., Leung, F. Y., Heald, C. L., Yantosca, R. M., Wu, S., Emmons, L. K., Edwards, D. P., and Sachse, G. W.: Inventory of boreal fire emissions for North America in 2004: Importance of peat burning and pyroconvective injection, J. Geophys. Res., 112, D12S03, doi:10.1029/2006JD007281, 2007. van der Werf, G. R., Randerson, J. T., Giglio, L., Collatz, G. J., Kasibhatla, P. S., and Arellano Jr., A. F.: Interannual variability in global biomass burning emissions from 1997 to 2004, Atmos. Chem. Phys., 6, 3423-3441, 2006, http://www.atmos-chem-phys.net/6/3423/2006/.

Yokelson, R. J., Bertschi, I. T., Christian, T. J., Hobbs, P. V., Ward, D. E., and Hao, W. M.: Trace gas measurements in nascent, aged, and cloud-processed smoke from African savanna fires by airborne Fourier transform infrared spectroscopy (AFTIR), J. Geophys. Res., 108, 8478, doi:10.1029/2002JD002322, 2003.

Yokelson, R. J., Urbanski, S. P., Atlas, E. L., Toohey, D. W., Alvarado, E. C., Crounse, J. D., Wennberg, P. O., Fisher, M. E., Wold, C. E., Campos, T. L., Adachi, K., Buseck, P. R., and Hao, W. M.: Emissions from forest fires near Mexico City, Atmos. Chem. Phys., 7, 5569-5584, 2007, http://www.atmos-chem-phys.net/7/5569/2007/.

Yokelson, R. J., Christian, T. J., Karl, T. G., and Guenther, A.: The tropical forest and fire emissions experiment: laboratory fire measurements and synthesis of campaign data, Atmos. Chem. Phys., 8, 3509-3527, 2008, http://www.atmos-chem-phys.net/8/3509/2008/.

Zhao, Y., Strong, K., Kondo, Y., Koike, M., Matsumi, Y., Irie, H., Rinsland, C. P., Jones, N. B., Suzuki, K., Nakajima, H., Nakane, H., and Murata, I.: Spectroscopic measurements of tropospheric $\mathrm{CO}, \mathrm{C}_{2} \mathrm{H}_{6}, \mathrm{C}_{2} \mathrm{H}_{2}$, and $\mathrm{HCN}$ in northern Japan, J. Geophys. Res., 107, 4343, doi:10.1029/2001JD000748, 2002. 